\title{
Financial Statement at Pentagon Shipping Service
}

\author{
CS Gowtham Chakrvarthy, S.Praveen Kumar, J.Pavithra
}

\begin{abstract}
A money related rundown assessment that sees sway that ascents in financing rehearses from effect that ascents in activities. The appraisal yields two utilizing conditions, one for verifying to back activities and one for getting over the scope of assignments. These utilizing conditions delineate how the two sorts of effect book paces of advantage for worth. An observational appraisal demonstrates that the monetary report assessment clarifies cross-sectional contrasts in present and future paces of return correspondingly as cost to-book degrees, which depend upon predicted paces of advantage for worth. The paper hence infers that monetary [31],[33],[32]record nuances for working liabilities are surveyed especially as opposed to those directing financing liabilities. In like manner, spending report assessment that sees the two sorts of liabilities educates on future productivity and helpers in the assessment of fitting cost to-book degrees. Degree appraisal is a usually utilized sound instrument for checking the presentation of a firm. While degrees are certainly not difficult to process, which to a compelled degree clarifies their wide intrigue, their explanation is tricky when in any occasion two degrees offer clashing insight. Obviously, degree evaluation is constantly analyzed on the grounds of subjectivity that is the masters must pick and pick degrees to survey the general execution of a firm. [1],[3],[5]

Keywords : ratio,analysis,interpretation
\end{abstract}

\section{INTRODUCTION}

Spending abstract Analysis is a technique for investigating and isolating an affiliation's bookkeeping reports (money related reports) so as to measure its past, present or predicted future execution. This 'methodology of examining the money related reports considers better monetary basic specialist. [2 ],[4],[6]

In this way, the rule motivation driving monetary once-over evaluation is to use data about the past presentation of the relationship so as to anticipate how it will area later on. [7],[ 9], [11]

We have starting at now gotten some answers concerning the arranging of monetary outlines in Balance Sheet and Trading and Profit and Loss Account in 'Spending reports of Profit and Not income driven Organizations'. After course of action

Revised Manuscript Received on July 22, 2019.

Mr. CS Gowtham Chakrvarthy, Department of MBA, Bharath Institute of Higher Education and Research, Tamilnadu, India. Email: chakravins@gmail.com

Dr.S.Praveen Kumar, Department of MBA, Bharath Institute of Higher Education and Research, Tamilnadu, India. Email: praveenkumar.mba@bharathuniv.ac.in

J.Pavithra, Department of MBA, Bharath Institute of Higher Education and Research, Tamilnadu, India. Email: pavithralect@yahoo.com of the monetary synopses, one may be enthusiastic about separating the spending outlines with the help of different instruments, for instance, close announcement, standard size clarification, extent assessment, design examination, finance stream examination, pay assessment, etc. In this technique a significant relationship is developed between at any rate two accounting figures for connection. In this I will use exploring the spending reports by using comparable declaration, normal size verbalization and example assessment. [8],[ 10] ,[12]

\section{OBJECTIVES}

- To comprehend the monetary exhibition of pentagon shipping

- To investigate the benefit and misfortune pentagon shipping

- To Assessment of Past Performance

- To Assessment of current position

- To Prediction of gainfulness and development prospects

- To think about and decipher fiscal report of pentagon shipping

- To give proposal to improving the general execution of the organization

- To Assessment of the operational effectiveness

\section{DATA ANALYSIS AND INTERPRETATION} Table:1 GROSS PROFIT RATIO

\begin{tabular}{|l|l|l|l|}
\hline Years & $\begin{array}{l}\text { Gross Profit } \\
(\text { Rs.) }\end{array}$ & $\begin{array}{l}\text { Net sales } \\
\text { (Rs.) }\end{array}$ & $\begin{array}{l}\text { Ratio } \\
\text { (In \%) }\end{array}$ \\
\hline $2014-2015$ & 30289.71 & 90176.44 & 33.58 \\
\hline $2015-2016$ & 21971.03 & 108277.62 & 20.29 \\
\hline $2016-2017$ & 32347.63 & 118189.37 & 27.37 \\
\hline
\end{tabular}




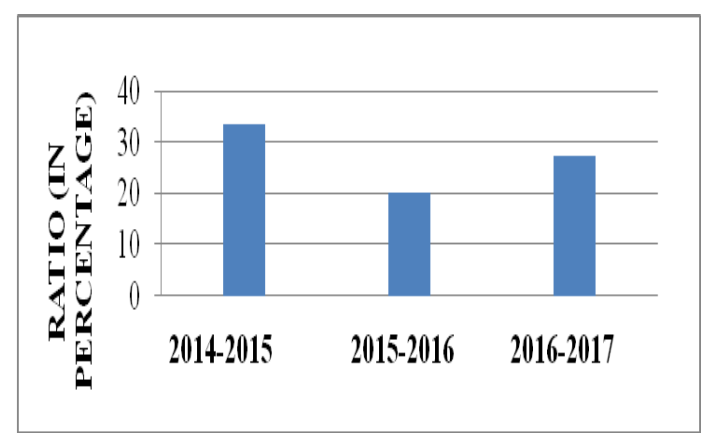

Fig:1 GROSS PROFIT RATIO

Table:2 NET PROFIT RATIO

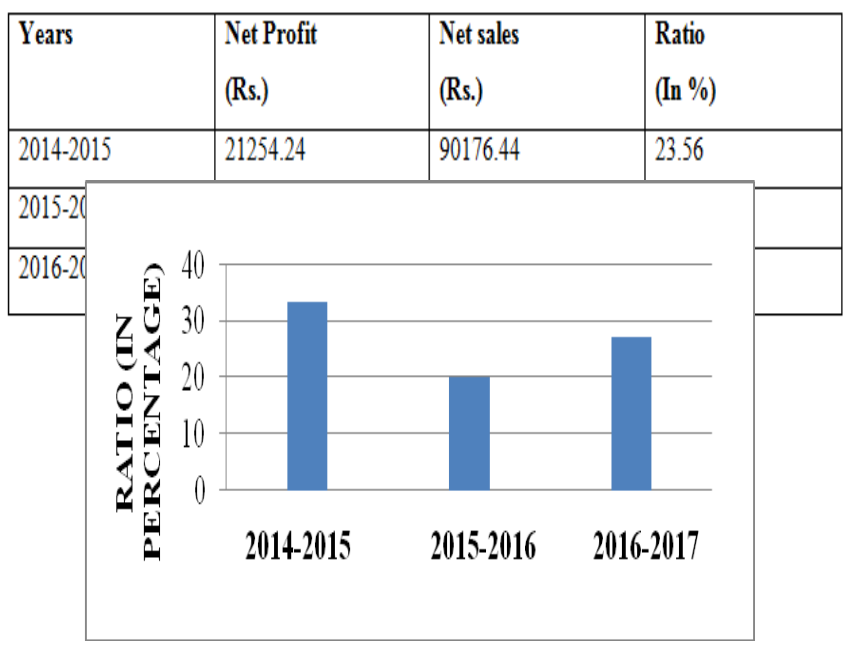

Fig:2 NET PROFIT RATIO

Table :3 RETURN ON EQUITY

\begin{tabular}{|l|l|l|l|}
\hline & $\begin{array}{l}\text { Net profit after } \\
\text { interest and tax } \\
\text { (Rs.) }\end{array}$ & $\begin{array}{l}\text { Shareholder } \\
\text { Fund (Rs.) }\end{array}$ & $\begin{array}{l}\text { Ratio } \\
\text { (In \%) }\end{array}$ \\
\hline $2014-2015$ & 21254.24 & 231280.81 & 9.18 \\
\hline $2015-2016$ & 15073.14 & 268538.97 & 5.61 \\
\hline $2016-2017$ & 22674.86 & 333318.07 & 6.80 \\
\hline
\end{tabular}

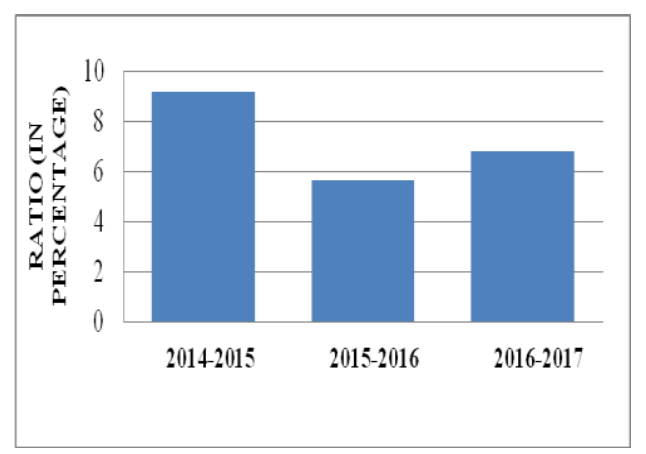

Fig:3 RETURN ON EQUITY

Table No 4. WORKING CAPITAL TURNOVER RATIO

\begin{tabular}{|l|l|l|l|}
\hline Years & $\begin{array}{l}\text { Sales } \\
\text { (Rs.) }\end{array}$ & $\begin{array}{l}\text { Net Working Capital } \\
\text { (Rs.) }\end{array}$ & $\begin{array}{l}\text { Ratio } \\
\text { (In Times) }\end{array}$ \\
\hline $2014-2015$ & 90176.44 & 645733.44 & 0.13 \\
\hline $2015-2016$ & 108277.62 & 666319.18 & 0.16 \\
\hline $2016-2017$ & 118189.37 & 898497.54 & 0.13 \\
\hline
\end{tabular}

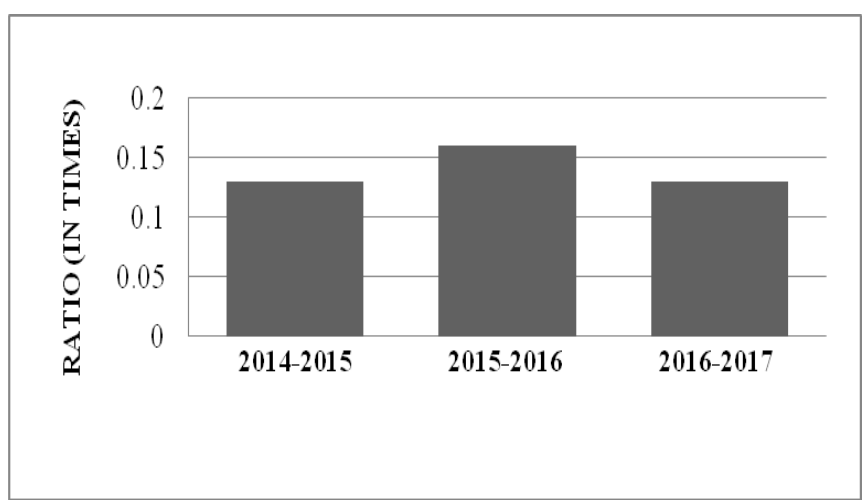

Fig:4 WORKING CAPITAL TURNOVER RATIO

Table No 5 CAPITAL TURNOVER RATIO

\begin{tabular}{|l|l|l|l|}
\hline Years & $\begin{array}{l}\text { Net Sales } \\
\text { (Rs.) }\end{array}$ & $\begin{array}{l}\text { Capital Employed } \\
\text { (Rs.) }\end{array}$ & $\begin{array}{l}\text { Ratio } \\
\text { (In Times) }\end{array}$ \\
\hline $2014-2015$ & 90176.44 & 536009.27 & 0.16 \\
\hline $2015-2016$ & 108277.62 & 533288.26 & 0.20 \\
\hline $2016-2017$ & 118189.37 & 720052.92 & 0.17 \\
\hline
\end{tabular}




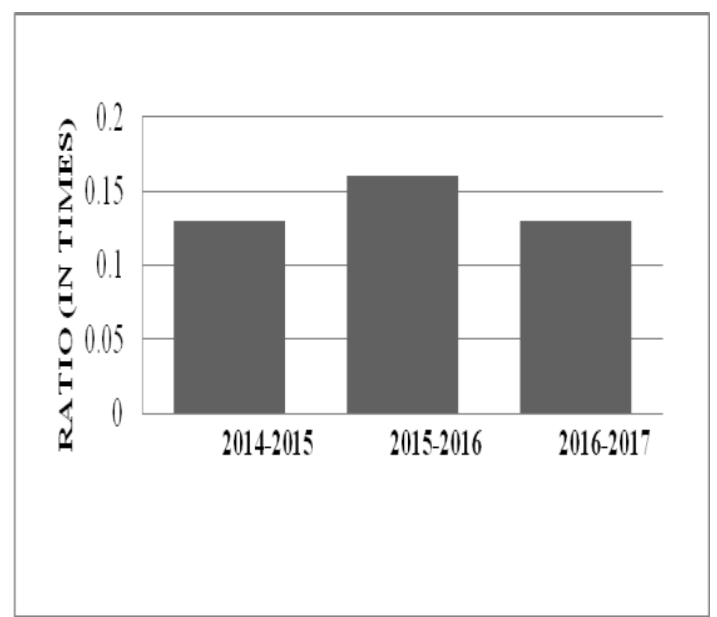

Fig.5 CAPITAL TURNOVER RATIO

Table.6 FIXED ASSET TURNOVER RATIO

\begin{tabular}{|l|l|l|l|}
\hline Years & $\begin{array}{l}\text { Sales } \\
\text { (Rs.) }\end{array}$ & $\begin{array}{l}\text { Fixed Asset } \\
\text { (Rs.) }\end{array}$ & $\begin{array}{l}\text { Ratio } \\
\text { (In Times) }\end{array}$ \\
\hline $2014-2015$ & 90176.44 & 17264.30 & 5.22 \\
\hline $2015-2016$ & 108277.62 & 20241.05 & 5.35 \\
\hline $2016-2017$ & 118189.37 & 23237.80 & 5.09 \\
\hline
\end{tabular}

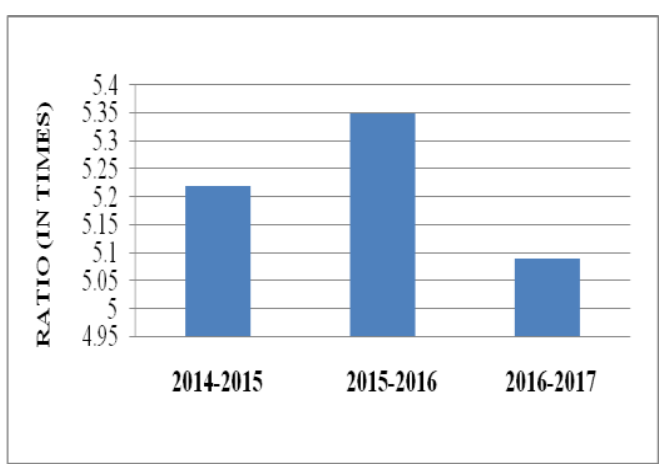

Fig.6 FIXED ASSET TURNOVER RATIO

Table: 7 CURRENT RATIO

\begin{tabular}{|l|l|l|l|}
\hline Years & $\begin{array}{l}\text { Current Asset } \\
\text { (Rs.) }\end{array}$ & $\begin{array}{l}\text { Current Liabilities } \\
\text { (Rs.) }\end{array}$ & $\begin{array}{l}\text { Ratio } \\
\text { (In Times) }\end{array}$ \\
\hline $2014-2015$ & 56187.53 & 5303.57 & 1.06 \\
\hline $2015-2016$ & 68876.04 & 50360.94 & 1.36 \\
\hline $2016-2017$ & 166489.36 & 55084.13 & 3.02 \\
\hline
\end{tabular}

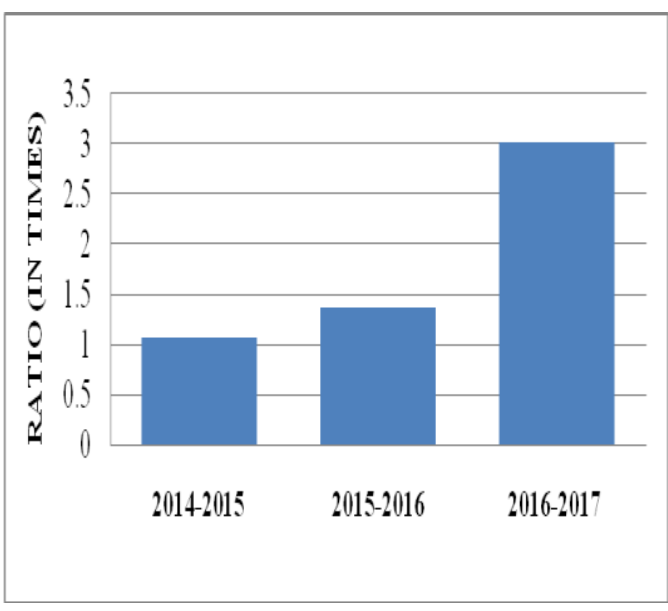

Fig: 7 CURRENT RATIO

Table : 8 DEBT EQUITY RATIO

\begin{tabular}{|l|l|l|l|}
\hline Years & $\begin{array}{l}\text { Long term debts } \\
\text { (Rs.) }\end{array}$ & $\begin{array}{l}\text { Shareholders funds } \\
\text { (Rs.) }\end{array}$ & $\begin{array}{l}\text { Ratio } \\
\text { (In Times) }\end{array}$ \\
\hline $2014-2015$ & 431716.93 & 104292.34 & 4.13 \\
\hline $2015-2016$ & 418021.26 & 115267 & 3.62 \\
\hline 2016.2017 & 588417.27 & 131635.65 & 4.47 \\
\hline
\end{tabular}

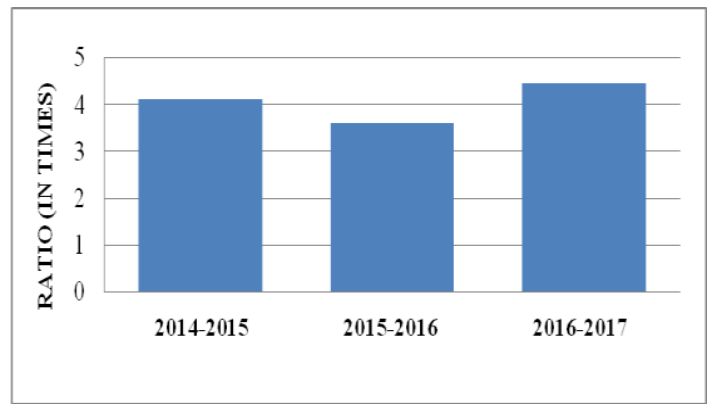

Fig:8 DEBT EQUITY RATIO

Table 9 DEBT TO TOTAL FUNDS RATIO

\begin{tabular}{|c|c|c|c|}
\hline Years & $\begin{array}{l}\text { Long Term Debts } \\
(\mathbb{R s s})\end{array}$ & $\begin{array}{l}\text { Total Funds } \\
\text { (Rs.) }\end{array}$ & $\begin{array}{l}\text { Ratio } \\
\text { (In Times) }\end{array}$ \\
\hline $2014-2015$ & 431716.93 & 712389.16 & 0.60 \\
\hline $2015-2016$ & 418021.26 & 742843.84 & 0.56 \\
\hline $2016-2017$ & 588447.27 & 981101379 & 0.59 \\
\hline
\end{tabular}


Financial Statement at Pentagon Shipping Service



Fig: 9 DEBT TO TOTAL FUNDS RATIO

\section{Table:10 CASH FLOW STATEMENT OF PENTAGON SHIPPING LIMITED FOR THE YEAR ENDED}

31.3.2017

\begin{tabular}{|c|c|c|}
\hline Particulars & $\begin{array}{l}2016-2017 \\
\text { In Rs.) }\end{array}$ & \\
\hline 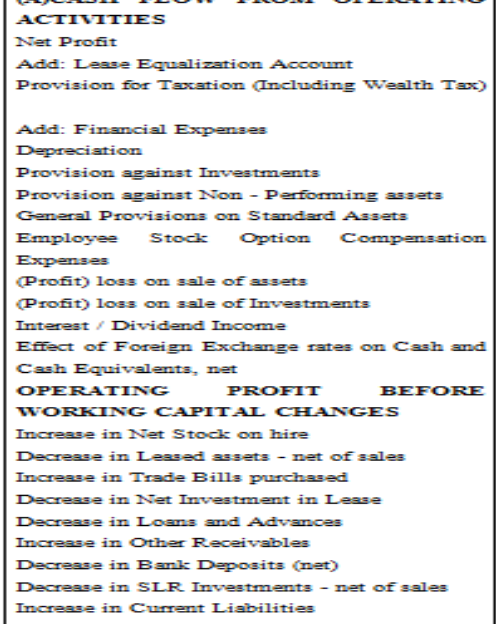 & $\begin{array}{c}67,08.38 \\
(60,87.57) \\
15,44.60 \\
(32.25) \\
(1465,04.17) \\
13.29 \\
(1079,89.81) \\
(22,40.77) \\
32,87.01 \\
\end{array}$ & $\begin{array}{c}956,35.33 \\
45,80.23 \\
1,44.64 \\
4,79.98 \\
31,61.69 \\
23.28 \\
34.21 \\
(53,36.95) \\
(22,00.38) \\
0.18 \\
\\
965,22.21\end{array}$ \\
\hline 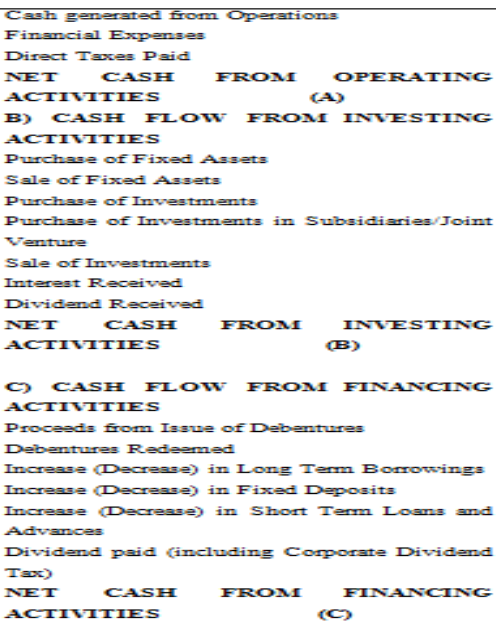 & $\begin{array}{l}(619,43.37) \\
(90,05.16)\end{array}$ & $\begin{array}{c}3475,75.18 \\
(2686,00.00) \\
869,13.98 \\
154,84.84 \\
417,96.83 \\
(53,51.34) \\
2178,19.49 \\
(0.18) \\
(21,68.65) \\
48,39.35\end{array}$ \\
\hline
\end{tabular}

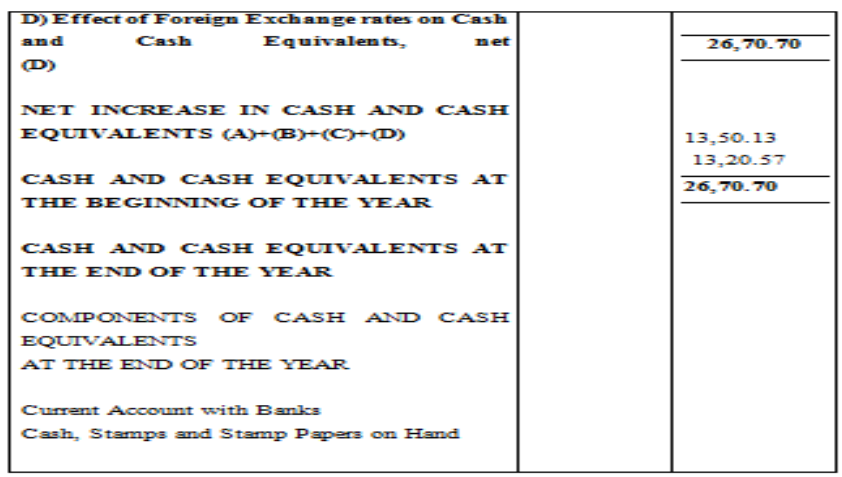

\section{RESULTS AND DISCUSSION}

- The present proportion is improving quickly so the organization needs to watch out for the present resources stream.

- The organization has been proposed to lessen the use as it expands each year. Abatement in costs will expand the productivity.

- By outlining the working capital turnover proportion obviously the organization needs to use its working capital productively that is the abundance current resources ought to be balanced by current situation. [25],[27],[29]

- Despite the fact that the net benefit demonstrates it is expanded yet we found that the net benefit proportion has been diminished.

- So the organization ought to consider expanding the deals thus to build the real benefit. [26],[28],[30]

- The obligation value proportion of the organization is additionally expanding.

- The organization should concentrate on the obligation and long haul finances which are used in the organization. [13], [15], , 17]

- The overabundance income ought to or can be used in any new pursuits if the organization wishes to do.

\section{V.CONCLUSION}

In the assessment of Financial Performance of Pentagon transportation Limited Chennai, clearly the affiliation's budgetary show is tasteful. The affiliation has stable improvement and it demonstrates an inexorably obvious gainfulness in the majority of the areas it works. [14],[ 16], [18]

In the event that the affiliation uses its working capital, by then the affiliation can go statures which it expected to accomplish. The relative pay articulation exhibits increment in the present year of net preferred position and it delineate the affiliations current bit of leeway position. To improve the reasonability the affiliation will attempt better execution and expansion the bit of the pie the affiliation. [19],[21],[23]

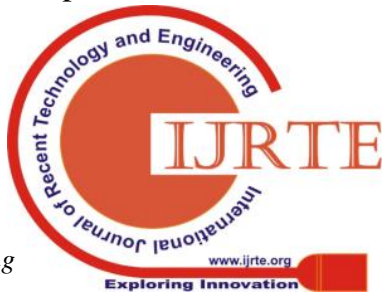


The suggestion gave through the evaluation will assist the relationship with improving the operational display beneficially. The suggestions gave through the assessment will help the association with improving the operational introduction profitably. [20],[22], [24]

\section{REFERENCES}

1. G BharthVajan R., Ramachandran S.,Psychographic dimensions of training,2016,International Journal of Pharmacy and Technology,V-8,I-4,P-23727-23729

2. Balakrishnan P., Bharthvajan R.,A study on human resource planning in hospitals in Chennai City,2014,International Journal of Applied Engineering Research,V-9,I-22,P-7503-7507

3. Priyadarsini P., Bharthvajan R.,Role of emotional intelligence training programme in reducing the stress of the nurses,2014,International Journal of Applied Engineering Research,V-9,I-22,P-7411-7421

4. Kerinab Beenu G., Bharthvajan R.,Empirical analysis on the cosmetic buying behavior of young women in South India,2014,International Journal of Applied Engineering Research,V-9,I-22,P-7361-7366

5. Balakrishnan P., Bharthvajan R.,Whistling in the wind,2014,International Journal of Applied Engineering Research,V-9,I-22,P-7586-7593

6. Krishnan B., Peter M.,Health hazards of Indian Bpo employee-an alarming issue,2014,International Journal of Applied Engineering Research,V-9,I-22,P-7336-7341

7. Kerinab Beenu G.H., Peter M.,Role of insurance in economic development,2014,International Journal of Applied Engineering Research,V-9,I-22,P-7532-7539

8. Balakrishnan P., Peter M., Priyadarsini P.,Efficiency of safety measures for wellbeing of employees in manufacturing industry,2014,International Journal of Applied Engineering Research,V-9,I-22,P-7376-7382

9. Anbarasi M., Praveen Kumar S.,Online sales promotions of herbal products and its effectiveness towards tanisha.com,2019,Indian Journal of Public Health Research and Development,V-10,I-1,P-195-200

10. Anbarasi M., Praveen Kumar S.,Various online marketing and promotions strategies to improve the validation towards the organic products in the pharmaceutical sectors,2019,Indian Journal of Public Health Research and Development,V-10,I-1,P-263-269

11. Loganathan R., Praveen Kumar S.,Grievance handling a key factor for solving issues of employees in an organization,2014,International Journal of Applied Engineering Research,V-9,I-22,P-7483-7491

12. Loganathan R., Praveen Kumar S.,Study on preference of private label brands in super and Hypermarkets,2014,International Journal of Applied Engineering Research,V-9,I-22,P-7327-7335

13. Smitha M., Praveen Kumar S.,Understanding stress and its managementamong the nurses in Chennai city,2014,International Journal of Applied Engineering Research,V-9,I-22,P-7560-7565

14. Kerinab Beenu G.H., Praveen Kumar S.,A study on the investment behavior of Chennai investors in mutual fund schemes,2014,International Journal of Applied Engineering Research,V-9,I-22,P-7520-7525

15. Loganathan R., Praveen Kumar S.,Retention strategies key for organizational productivity,2014,International Journal of Applied Engineering Research,V-9,I-22,P-7443-7447

16. Pavithra J., Ganesan M., Brindha G.,State wise analysis of microfinance sector in India,2016,International Journal of Pharmacy and Technology,V-8,I-4,P-23417-23432

17. Pavithra J., Ganesan M.,A comparative study on microfinance in India and abroad,2016,International Journal of Applied Business and Economic Research,V-14,I-8,P-5471-5476

18. Pavithra J., Ganesan M.,A study on awareness and impact of micro-financial schemes,2016,International Journal of Applied Business and Economic Research,V-14,I-8,P-5449-5460

19. Senthilmurugan P., Pavithra J.,Consumer preference towards organised retailing with reference to Big Bazaar,2014,International Journal of Applied Engineering Research,V-9,I-22,P-7469-7475

20. Senthilmurugan P., Pavithra J.,Implication of social media marketing in growing healthcare industry,2014,International Journal of Applied Engineering Research,V-9,I-22,P-7448-7456

21. Loganathan R., Pavithra J.,Consumer perception towards private label brand over other brands in super markets and hypermarkets,2014,International Journal of Applied Engineering Research,V-9,I-22,P-7355-7360
22. Kerinab Beenu G., Pavithra J.,Tradeâ€"off between liquidity and profitability in logistics industry,2014,International Journal of Applied Engineering Research,V-9,I-22,P-7398-7401

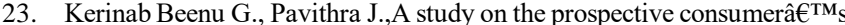
perception towards utility cars in Chennai city,2014,International Journal of Applied Engineering Research,V-9,I-22,P-7526-7531

24. Pavithra J., Dilli Babu P., Ambuli T.V.,A study on budgetary control at Maruti Service Masters, Chennai,2014,International Journal of Applied Business and Economic Research,V-12,I-2,P-151-161

25. Pavithra J., Dilli Babu P., Ambuli T.V.,A study on customer satisfaction of retro Garments Pvt Ltd, Chennai,2014,International Journal of Applied Business and Economic Research,V-12,I-2,P-381-391

26. Kerinab Beenu G.H., Pavithra J., Senthilmurugan P.,A study on the influence of promotional activities for TATA ARIA among consumers in Chennai,2014,International Journal of Applied Engineering Research,V-9,I-22,P-7572-7578

27. Vijayaragavan S.P.,An investigative expert that's general FBG sensors,International Journal of Mechanical Engineering and Technology,V-8,I-8,PP-1500-1505,Y-2017

28. Vijayaragavan S.P.,Equalization routing protocol for Wi-Fi sensor strategy,International Journal of Mechanical Engineering and Technology,V-8,I-8,PP-1662-1666,Y-2017

29. Karthik B., Kiran Kumar T.V.U., Vijayaragavan P., Bharath Kumaran E.,Design of a digital PLL using 0.35 $\hat{\mathrm{I}}^{1 / 4} \mathrm{~m}$ CMOS technology,Middle East Journal of Scientific Research,V-18,I-12,PP-1803-1806,Y-2013

30. Kanniga E., Selvaramarathnam K., Sundararajan M.,Kandigital bike operating system,Middle - East Journal of Scientific Research,V

31. Jasmin M., Vigneshwaran T., Beulah Hemalatha S.,Design of power aware on chip embedded memory based FSM encoding in FPGA,International Journal of Applied Engineering Research,V-10,I-2,PP-4487-4496,Y-2015

32. Jasmin M.,Optimization techniques for low power VLSI circuits,Middle East Journal of Scientific Research,V-20,I-9,PP-1082-1087,Y-2014

33. Jasmin M., Vigneswaran T.,Fuzzy controller for error control of on - Chip communication,2017 International Conference on Algorithms, Methodology, Models and Applications in Emerging Technologies, ICAMMAET 2017,V-2017-January,I-,PP-1-5,Y-2017

\section{AUTHORS PROFILE}



Gowtham Chakravarthy,Assistant Professor ,Department of MBA, Bharath Institute of Higher Education and Research, Tamilnadu, India

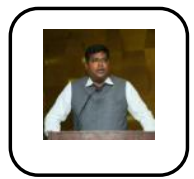

Dr.S.Praveen Kumar, Professor ,Department of MBA Bharath Institute of Higher Education and Research, Tamilnadu, India

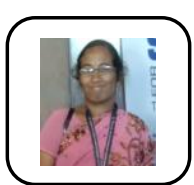

J.Pavithra,Assistant Professor ,Department of MBA Bharath Institute of Higher Education and Research, Tamilnadu, India. 